\title{
Commentary: Differential Effects of High-Protein Diets Derived from Soy and Casein on Blood-Brain Barrier Integrity in Wild-type Mice
}

\author{
Niva Shapira ${ }^{1,2 *}$ \\ ${ }^{1}$ Department of Nutrition, Ashkelon Academic College, Ashkelon, Israel, ${ }^{2}$ Rabin Medical Center, Institute of Nutrition \\ Research, Petah Tikva, Israel
}

Keywords: dietary protein, casein, methionine, homocysteine, B-vitamins, Mediterranean diet

\section{A commentary on}

Differential Effects of High-Protein Diets Derived from Soy and Casein on Blood-Brain Barrier Integrity in Wild-type Mice

by Snelson M, Mamo JCL, Lam V, Giles C, Takechi R. Front. Nutr. (2017) 4:35. doi: $10.3389 /$ fnut.2017.00035

OPEN ACCESS

Edited by: Kazim Sahin,

Firat University, Turkey

Reviewed by:

Osman Küçük,

Erciyes University, Turkey

Ertugrul Kilic,

Istanbul Medipol University, Turkey

*Correspondence:

Niva Shapira

nivnet@inter.net.il

Specialty section:

This article was submitted to

Clinical Nutrition

a section of the journal

Frontiers in Nutrition

Received: 04 December 2017

Accepted: 16 July 2018

Published: 08 August 2018

Citation:

Shapira N (2018) Commentary:

Differential Effects of High-Protein

Diets Derived from Soy and Casein on

Blood-Brain Barrier Integrity in

Wild-type Mice. Front. Nutr. 5:67.

doi: 10.3389/fnut.2018.00067
Following repeated observations that a high-protein diet may induce cognitive decline, and that proteins from various foods demonstrate differential effects on cognition, the recent study by Snelson et al. (1) examined potential mechanisms in a murine model. The team compared protein from different sources for influence on blood brain barrier permeability and inflammation, which are increasingly accepted as pivotal measures for central nervous system function. As casein showed much stronger effects than soy protein-having much higher methionine compared to soy protein, which is higher in cysteine-and methionine being the leading amino acid associated with elevated plasma homocysteine (Hcy) levels $(2,3)$, it may be assumed that high Hcy is involved in these damaging processes in the brain.

Previous studies reported that high Hcy is associated with compromised cerebrovascular function, including blood brain barrier dysfunction (4), increased permeability and neuroinflammation $(5,6)$, and structural and functional alterations via promotion of oxidative stress (7), with methionine being the leading amino acid associated with elevated plasma Hcy levels $(2,3)$.

A recent clinical study on a high-casein meal-incorporating large oral boli of 5\% fat and $11 \%$ protein cottage cheese, which has mostly casein protein-showed that blood Hcy was moderately increased for about $5-8 \mathrm{~h}$ postprandially (8). However, this Hcy response to cheese was reduced by acute addition of vitamin B6 (pyridoxine) and folic acid. These B-vitamins, in addition to B2 (riboflavin) and B12 (cobalamin), are highly active in the methionine metabolic cycle, but largely removed with whey in the cheese production process (Figure 1) (8). Especially vulnerable is vitamin B6, a key cofactor in Hcy metabolism (9), highly dominant in the trans-sulfuration stage and critical under high-protein conditions. While the required minimum B6:protein ratio is $15-20 \mu \mathrm{g} \mathrm{B6} / \mathrm{g}$ protein (10), that of cottage cheese is generally much lower, i.e., $\approx 1.86 \mu \mathrm{g} / \mathrm{g}$ $(\approx 6.2$-fold lower than the $\geq 11.52 \mu \mathrm{g} / \mathrm{g}$ of milk $(11)$, and lower than experimental vitamin B6depleting diet providing $<0.5 \mu \mathrm{g} / \mathrm{g}(10,12)$. Thus, high casein intake (including through cottage cheese) can correspondingly be perceived as a highly B6-deficient/demanding meal that if not co-supplemented, may temporarily increase Hcy. 


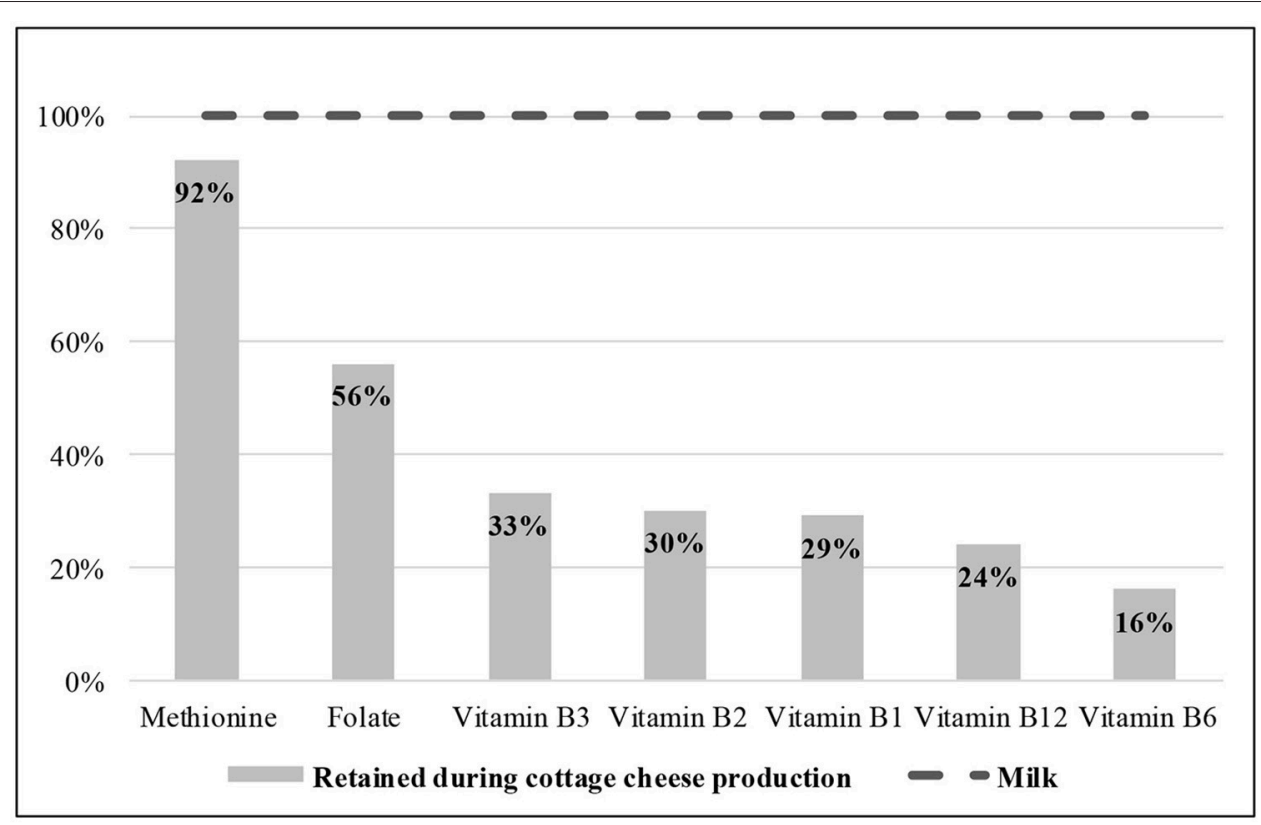

FIGURE 1 | Methionine and B-vitamins, \% retained in cottage cheese (USDA ID: 01015) vs. milk (representing 100\%). Adapted from Shapira (8) with permission from The Royal Society of Chemistry.

Together, these studies emphasize that the potential for damage attributable to casein-through its high methionine content compared to soy protein having high cysteine content, as shown in the rat study-may be applicable to human diet, i.e., in case of high cottage cheese consumption, shown to be associated with transient (for several hours) increases in Hcy. This may suggest that high-casein foodsprimarily cheese-would be better consumed together with complementary B-vitamins, preferably from foods-especially B6, e.g., from fish, poultry, sweet potato, potato, sunflower seeds, spinach, banana, and folic-acid, e.g., from beans, spinach, broccoli, leafy vegetables, tomato, bell pepper, carrots, oranges-that may compensate for the secondary B-vitamin insufficiency resulting from their removal with whey during cheese production, and would prevent temporal increase of Hcy.

With regard to the authors' aims toward dietary recommendations, we would like to emphasize the importance of food combinations, i.e., as shown by the Greek salad of the

\section{REFERENCES}

1. Snelson M, Mamo JCL, Lam V, Giles C, Takechi R. Differential effects of highprotein diets derived from soy and casein on blood-brain barrier integrity in wild-type mice. Front. Nutr. (2017) 4:35. doi: 10.3389/fnut.2017.00035

2. Ditscheid B, Fünfstück R, Busch M, Schubert R, Gerth J, Jahreis G. Effect of Lmethionine supplementation on plasma homocysteine and other free amino acids: a placebo-controlled double-blind cross-over study. Eur J Clin Nutr (2005) 59:768-75. doi: 10.1038/sj.ejcn.1602138

3. Jakubowski H. Pathophysiological consequences of homocysteine excess. $J$ Nutr. (2006) 136(6 Suppl):1741S-9S. doi: 10.1093/jn/136.6.1741S
Mediterranean diet-where cheese is consumed within the salad context, together with vegetables, nuts and herbs, that would potentially compensate for insufficiencies or losses of B-vitamins, and olive oil increasing the anti-oxidative capacity vs. the Hcy-associated oxidative potential-together protecting against temporal effect of high consumption of methionine sources unopposed by sufficient B-vitamins.

Considering that cheese is currently a major protein source, including in women of childbearing age and in children-already from very young age-the findings in Snelson et al. (1) emphasize both the need to differentiate between sources of protein, especially during the critical periods of the brain development, and specifically the importance of food combinations and systematic balancing of all meals and of the complete diet.

\section{AUTHOR CONTRIBUTIONS}

The author confirms being the sole contributor of this work and approved it for publication.

4. Korai M, Kitazato KT, Tada Y, Miyamoto T, Shimada K, Matsushita N, et al. Hyperhomocysteinemia induced by excessive methionine intake promotes rupture of cerebral aneurysms in ovariectomized rats. J Neuroinflamm. (2016) 13:165. doi: 10.1186/s12974-016-0634-3

5. Kamat PK, Kalani A, Givvimani S, Sathnur PB, Tyagi SC, Tyagi N. Hydrogen sulfide attenuates neurodegeneration and neurovascular dysfunction induced by intracerebral-administered homocysteine in mice. Neuroscience (2013) 252:302-19. doi: 10.1016/j.neuroscience.2013. 07.051

6. Kalani A, Kamat PK, Givvimani S, Brown K, Metreveli N, Tyagi SC, et al. Nutri-epigenetics ameliorates blood-brain barrier damage and 
neurodegeneration in hyperhomocysteinemia: role of folic acid. $J$ Mol Neurosci. (2014) 52:202-15. doi: 10.1007/s12031-013-0122-5

7. Tyagi N, Kumar M, Pushpakumar SB, Lominadze D, Moshal KS, Sen $\mathrm{U}$. Homocysteine attenuates blood brain barrier function by inducing oxidative stress and the junctional proteins. FASEB J (2008) 22:734.7.

8. Shapira N. Cheese 'refinement' with whey B-vitamin removal during precipitation potentially induces temporal 'functional' dietary shortage: homocysteine as a biomarker. Food Funct. (2014) 5:1587-93. doi: 10.1039/C4FO00148F

9. Finkelstein JD. The metabolism of homocysteine: pathways and regulation. EurJ Pediatr. (1998) 157(Suppl 2):S40-4. doi: 10.1007/PL000 14300

10. Kretsch MJ, Sauberlich HE, Skala JH, Johnson HL. Vitamin B-6 requirement and status assessment: young women fed a depletion diet followed by a plant- or animal-protein diet with graded amounts of vitamin B-6. Am J Clin Nutr. (1995) 61:1091-101. doi: 10.1093/ajcn/61. 5.1091
11. USDA. USDA National Nutrient Database for Standard Reference (2011). Available online at: http://www.nal.usda.gov/fnic/foodcomp/search/.

12. Turnlund JR, Keyes WR, Hudson CA, Betschart AA, Kretsch MJ, Sauberlich HE. A stable-isotope study of zinc, copper, and iron absorption and retention by young women fed vitamin B-6-deficient diets. Am J Clin Nutr. (1991) 54:1059-64. doi: 10.1093/ajen/54.6.1059

Conflict of Interest Statement: The author declares that the research was conducted in the absence of any commercial or financial relationships that could be construed as a potential conflict of interest.

Copyright $\odot 2018$ Shapira. This is an open-access article distributed under the terms of the Creative Commons Attribution License (CC BY). The use, distribution or reproduction in other forums is permitted, provided the original author(s) and the copyright owner(s) are credited and that the original publication in this journal is cited, in accordance with accepted academic practice. No use, distribution or reproduction is permitted which does not comply with these terms. 